\title{
Meme-ing Electoral Participation
}

\section{Benita Heiskanen}

\section{(2) OpenEdition}

\section{Journals}

Electronic version

URL: https://journals.openedition.org/ejas/12158

DOI: 10.4000/ejas. 12158

ISSN: 1991-9336

Publisher

European Association for American Studies

\section{Electronic reference}

Benita Heiskanen, "Meme-ing Electoral Participation", European journal of American studies [Online],

12-2 | 2017, document 8, Online since 02 August 2017, connection on 08 December 2022. URL: http:// journals.openedition.org/ejas/12158; DOl: https://doi.org/10.4000/ejas. 12158

This text was automatically generated on 8 July 2021.

\section{(c) (i) \&}

Creative Commons - Attribution-NonCommercial 4.0 International - CC BY-NC 4.0

https://creativecommons.org/licenses/by-nc/4.0/ 


\title{
Meme-ing Electoral Participation
}

\author{
Benita Heiskanen
}

Internet memes have emerged as the lingua franca of the modern campaign.

USA Today

I also believe... that it is through the re-appearance of this knowledge, of these local popular knowledges, these disqualified knowledges, that criticism performs its work.

Michel Foucault, Power/Knowledge $e^{\mathrm{ii}}$

\section{Introduction}

1 In February 2016, the Washington Post characterized the presidential primaries as "the most-memed election in U.S. history" as a partial explanation of Bernie Sanders's unlikely challenging of Hillary Clinton's presumptive candidacy in the 2016 primaries. iii The "Bernie Sanders Dank Meme Stash" (BSDMS), created by two college students in 2015, had close to 450,000 followers in May 2016. ${ }^{\text {iv }}$ In September 2016, the Independent published a prescient article entitled, "Memes, Not Her Health, Could Cost Hillary Clinton the US Presidential Race," calling attention to the appeal of memes as an alternative to mainstream media "in decline," with a forewarning that "politicians are ignoring them at their own peril."v While meme-makers drawn to the Sanders campaign were most vocal and visible during the primary season, an October 2016 article by the New York Times pointed to a burgeoning of memes created by the proTrump community on 4chan and Reddit. ${ }^{\text {vi }}$ Although it was up to debate-due to a lack of quantitative evidence-whether memes were capable of impacting de facto political behavior, the consensus in mainstream newspapers was that they had a remarkable ability to engage people who were not ordinarily involved in bipartisan political processes. In their post-election analysis, Rodney Taveira and Emma Balfour contend: "If news pundits had been paying closer attention to memes, they might have been less shocked by the result of the 2016 US presidential election. Election memes reflected the political narrative of Hillary Clinton's inauthenticity and corruption, and Donald Trump's capacity to understand and connect to his followers." vii Hillary Clinton was the subject of a whole host of meme-ing, but early on her campaign attracted conspicuously more critical representations than that of Sanders. Trump's active 
attempts to connect with his voter base on various social media platforms particularly strengthened his image as being in touch with the public in ways that Clinton's campaign failed to. . vii

In this article, I want to consider the broader popularization of the 2016 presidential election through examples of meme-ing in relation to both the Republican and Democratic campaigns. I will discuss user-generated Internet memes, comprising text superimposed on an image, modified and remixed by users, and circulated in social media, as a form of electoral participation. Although memes take multiple different formats, ranging from images, videos, GIFs, and hyperlinks, due to the plethora of materials, my focus here will be on still macro images alone. The emergence of mememaking sites and databases-such as knowyourmeme.com, quickmeme.com, memegenerator.com, memecenter.com, memecreator.org, imgflip.com, reddit.com, 4chan.org, tumblr.com, and electmeme.lol-exemplifies the ways in which popular culture and new media platforms shaped the 2016 race across the political spectrum. Elect Meme's mission statement is explicit about its goal: "We think the 2016 US Presidential Elections could be one of the most important elections in history. We hope that this, in its own small way, helps engage a new generation of political participants on both sides of the aisle." ${ }^{\text {ix }}$ Indeed, meme-ing activated a group of voters that were not likely to be engaged in electoral politics, but who-through social media-developed a vested interest in the political process. Jenna Levers explains the function of meme-ing among Sanders supporters in this way: "This is how young people communicate to each other that they are \#FeelingtheBern. Sure one could easily say, I'm voting for Sanders because he's an awesome politician, I like his universal health care plan, I like his stance on college tuition and the middle class, but why say all that when you can say it all with a simple meme?"x

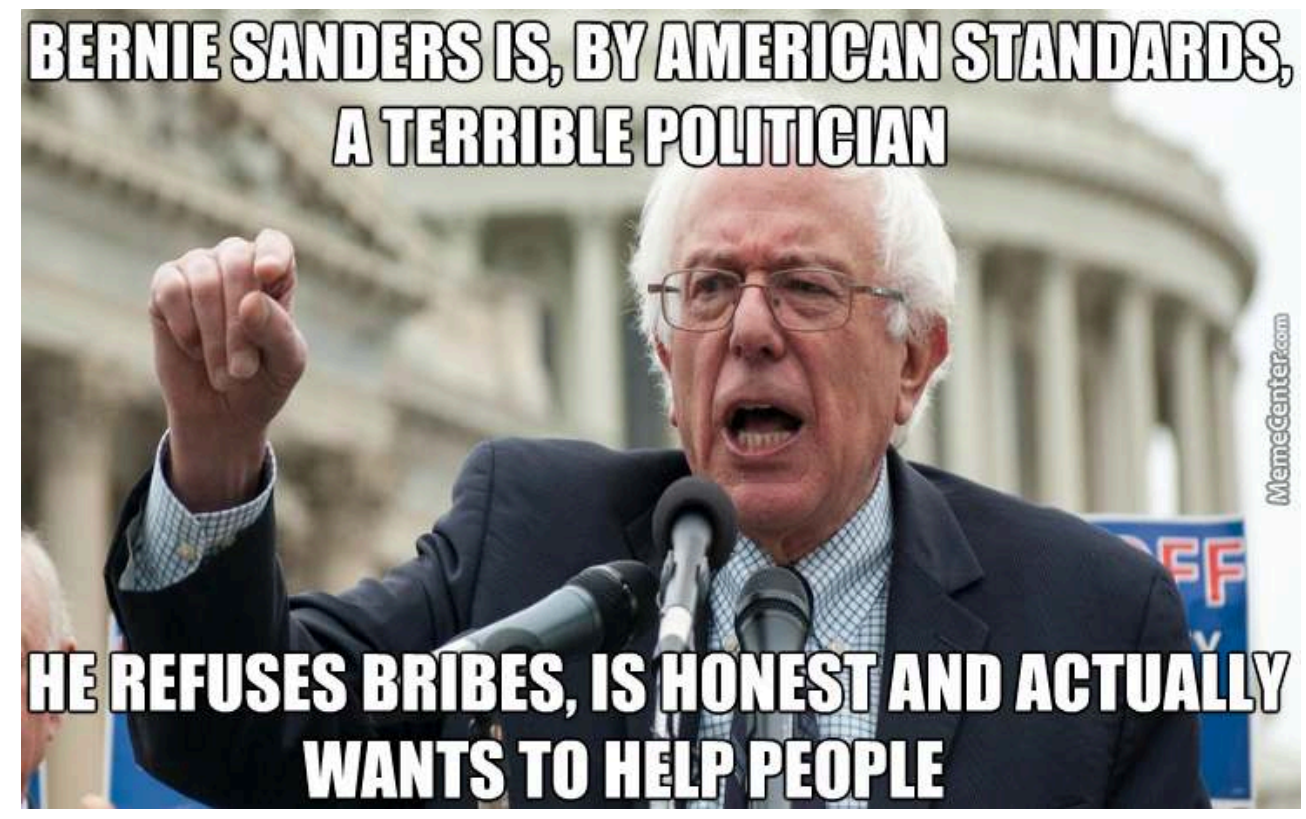

Figure 1. "Feel Da Bern," MemeCenter.com. ${ }^{\mathrm{xi}}$

The irony with which Sanders's positive characteristics were twisted into negative ones particularly struck a chord with a range of grassroots activists previously engaged in the Occupy Wall Street Movement, which sought to call attention to the corruption of mainstream bipartisan politics and the unequal distribution of wealth and resources. 
Despite the wide popularity of meme-ing among the grassroots electorate, some commentators arguing against memes have called attention to their unintended consequences, evoking a freedom of speech issue. ${ }^{\text {xi }}$ Indeed, the controversy surrounding Internet memes entails far-reaching epistemological implications about hierarchies of knowledge. In this article, I will first probe the politico-cultural intersections of Internet memes; I will then look at specific hot-button issues that prompted the interest of meme-makers during the 2016 election cycle; and, finally, I will consider the various ramifications that meme-ing has for our understanding of knowledge production processes within the electoral context.

\section{The Politico-Cultural Nexus of Internet Memes}

5 The standard etymological origin of the term "meme" is attributed to biologist Richard Dawkins's 1976 book The Selfish Gene, in which he defines memes as the cultural equivalents of biological genes: "Just as genes propagate themselves in the gene pool by leaping from body to body... so memes propagate themselves in the meme pool by leaping from brain to brain." ${ }^{\text {xiii }}$ Internet memes have been analyzed from various viewpoints-including Cultural Studies, Media Studies, Folklore, Anthropology, Political Science, and Computer Science-but their particular appeal is their inherently transdisciplinary and intertextual nature: that they don't neatly fall within a singular discipline or approach. According to Heidi E. Huntington, Internet memes are "best understood as groups of digital items or texts created and shared separately by many individuals but in awareness of one another and having common characteristics." ${ }^{\text {iv }}$ In her pioneering study Memes in Digital Culture, Limor Shifman emphasizes intertextuality and the convergence of various media platforms as key characteristics of Internet memes. ${ }^{\mathrm{xv}}$ One central tension evident in discussions about Internet memes is whether they are to be defined as primarily "cultural" or "political." In his analysis of meme-ing in the context of the Occupy Wall Street Movement, Stefka Hristova questions whether digital media as such can serve as a site for politics. Hristova claims: "I am suspicious about the extent to which digital space can be utilized effectively for political dissent and I argue that digital space has remained the space of the civil and the cultural, and not of the political."xvi In Shifman's opinion, however, memes serve as "multiparticipant creative expressions through which cultural and political identities are communicated and negotiated."xvii In turn, Ryan Milner defines Internet memes as "multimodal artifacts remixed by countless participants, employing popular culture for public commentary.... Image memes, in their very form, house potential for populist expression and conversation."xviii Milner's argument about memes' particular appropriateness for populist agendas helps to explain their appeal among Sanders and Trump voters during the 2016 election.

6 Rather than considering the question of culture and politics as an either-or question, my examination underscores the interdependent nature of politics and culture as a bothand matter: that politics do not take place outside of culture, just as culture does not take outside of politics. Although this is neither a new nor a groundbreaking insight, it is one that is frequently overlooked in discussions of electoral politics and, hence, warrants attention. ${ }^{\text {xix }}$ Indeed, we would be remiss in considering popular culture related to electoral politics as just "entertainment," for it has an important role in meaning-making and in reflecting ongoing political trends. Most people around the 
world likely spend more time following popular culture than partisan political debates, but in the United States, in particular, where voter turnout is relatively low, popular culture has an absolutely central role in representations of political phenomena. For that reason, it would serve us well to critically analyze the broader ramifications of the popularization of electoral politics, especially as displayed on the Internet.

In the context of the 2016 presidential election, the phenomenon of meme-ing represents a mode of politico-cultural discourse that exemplified the unusual election year in ways that conventional political analysis alone was not able to capture. Internet memes call attention to candidates' contradictory or incongruous statements, as well as critique their policy positions, thus enabling one's agency in political processes. Although Internet memes share some characteristics with political cartoons, the differentiating factor between them is that memes are participatory by nature, thus enabling users to modify them for their individual purposes. ${ }^{\mathrm{xx}}$ According to a study conducted by Vasiliki Plevriti, meme-makers participating in a focus group "insisted that they worked to unmask 'rotten' politicians or to raise awareness about situations they deemed as in need of change and improvement." "xi By highlighting issues that are especially controversial, Internet memes appeal to emotions and, in so doing, can have both a polarizing and galvanizing function. Yet the basic assumption behind mememaking is that recipients need to "get" the meme in order to be in on the joke; if not, the meme loses its potential. For this reason, Internet memes are more powerful when distributed within a peer group of already likeminded users. This makes it difficult to predict whether they change political behavior.

8 Looking at the 2016 presidential election cycle in its entirety, from the first candidacy announcements in early 2015 to the post-election analysis of January 2017, presents a fascinating "dramatic arc." As brief, to the point, and quickly modifiable visual-textual messages, Internet memes are a particularly apt way to illustrate this dramatic arc in line with the most contested hot-button issues that emerged during the race. As we know in hindsight, the preconceptions at the beginning of the primaries could not be further from what actually transpired. The fear that the election would be a battle between two tired political dynasties, with Jeb (John Ellis) Bush and Hillary Rodham Clinton as the presumptive nominees, seemed at the end of the primaries a light-year away. Yet, what is fascinating about looking back at memes that expressed disbelief about the prospect of a Bush-Clinton race-or political cartoons lambasting the upcoming election as a "sequel of a sequel"xxii or the "worst regifting ever" $x x i i$-is that they effectively underscore the ways in which both political insiders and laymen were oblivious to, and bamboozled by, the burgeoning of the populist insurgency in both parties. 


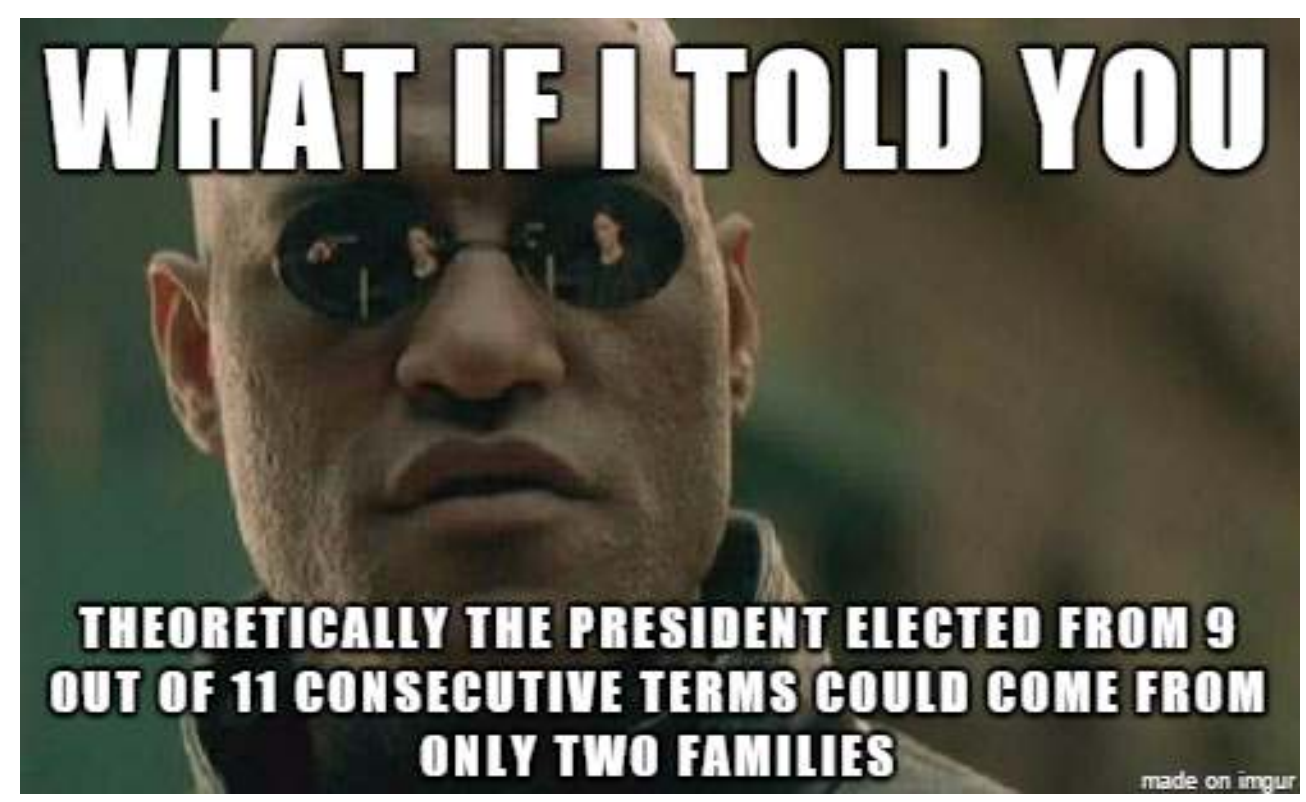

Figure 2. "The More You Know," Imgur. xxiv

Seasoned political analysts could neither predict the success of Donald Trump nor that of the self-proclaimed "Democratic Socialist" Bernie Sanders's challenge of the Democratic frontrunner Hillary Clinton. The intensity of defiance against establishment politics in both Republican and Democratic fields during the primary season surprised the elite of both parties, with centrist Democrats stubbornly refusing to believe its potential impact until the bitter end of the primaries. Even though President Barack Obama had run on a platform of change in 2008, the 2016 electorate wanted to walk the walk of a de facto change eight years later. While Obama remained popular among his liberal base, Trump and Sanders's ability to mobilize a vast base of previously inactive voters from diverse backgrounds steered the course of the election year and the rhetoric involved. The vigorous grassroots participation that the unconventional, populist campaigns attracted also brought electoral politics to social media in unprecedented ways. Although both the 2008 and 2012 campaigns had seen a growing presence of social media in electoral discourses, the 2016 campaign, coinciding with the so-called post-factual era, brought their influence to an entirely different level. ${ }^{\mathrm{xx}}$

\section{The Unpopular Candidates' Shifting Policy Positions}

11 Among the exceptional aspects of the 2016 presidential race was that both parties' nominees, Hillary Rodham Clinton and Donald J. Trump, came across as untrustworthy, which led to conspicuously high unfavorability ratings. A central motif for election memes came from the candidates' inconsistent self-representations or policy positions. Hillary Clinton earned the nickname of "flip-flopper" par excellence because of her habit to opportunistically switch positions on key issues. During the primaries, when Bernie Sanders's support was growing, Clinton significantly steered her policy positions toward the left-wing of the Democratic Party to appeal to his progressive base. For example, though she had previously been an avid supporter of the Trans-Pacific Partnership (TPP), Clinton changed her position against it in response to Sanders's vocal opposition of the trade deal. After winning the nomination, however, Clinton's 
choice of newly hired advisors suggested that she would not be honoring the newlyadopted positions, ostensibly made to please Sanders's supporters during the primaries. In the end, some of these voters moved to back the Green Party's candidate Jill Stein, others stayed home on Election Day, while yet others may have cast their ballot for Trump. During the 2016 campaign, the Black Lives Matter activist campaign also exposed Clinton's various shifting positions, from the time she served as First Lady in the 1990s up to the present, again signaling her alleged untrustworthiness.

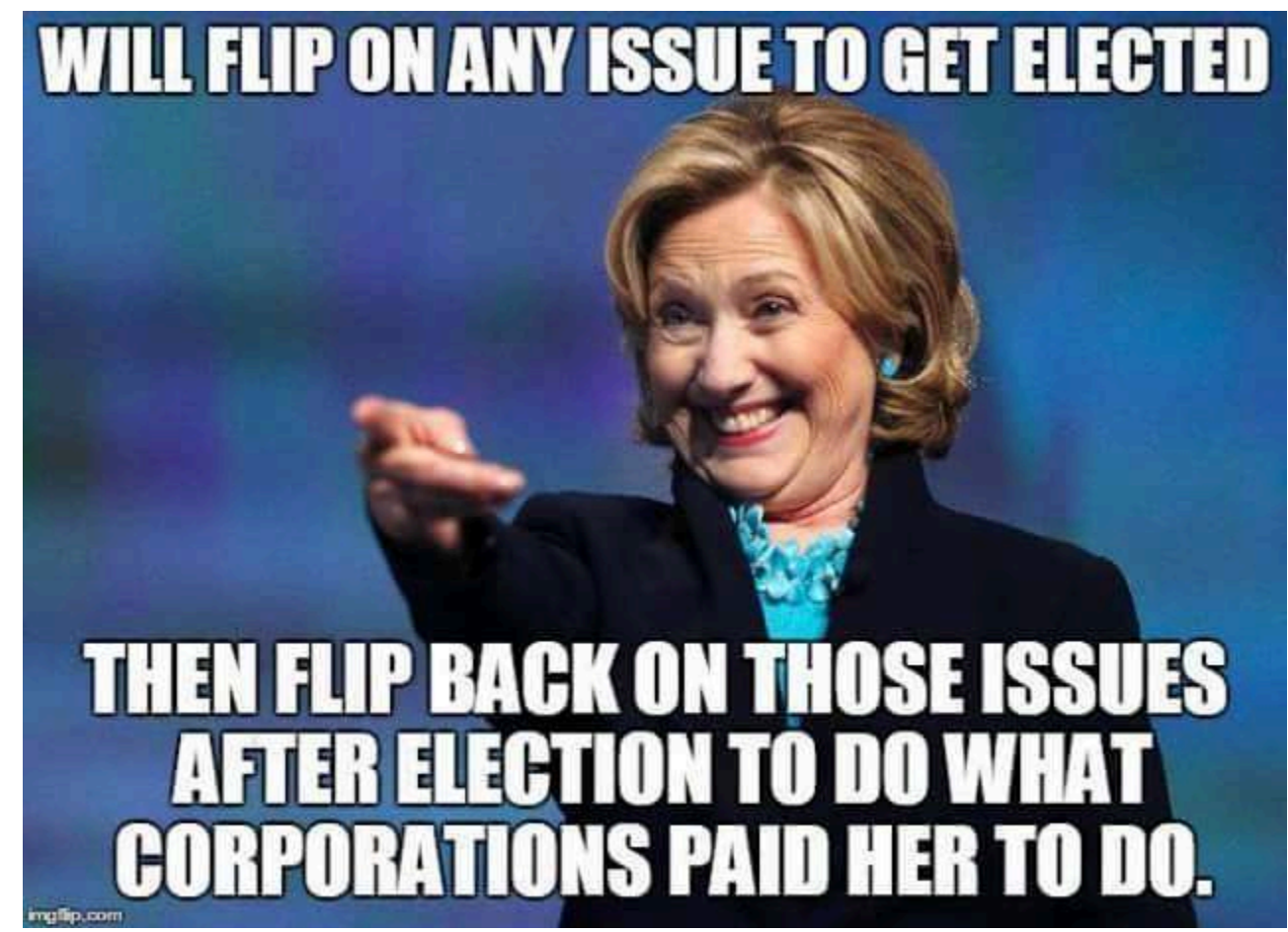

Figure 3. "Hillary Clinton Flip Flops," Imgur. xxvi

Similarly, Donald Trump's ambiguous political viewpoints, reflected in his previous donations to the Democratic Party and positions diametrically opposite to conservative Republicans, served as cues for the flip-flopping motif. Drawing on myriad examples of his past statements in the media from the 1980s onward, progressive critics were able to paint an image of a candidate who either had no road map of where he would like to take the country or just lacked any consistency or moral compass guiding his actions. A major question mark hovering over Trump's presidential bid was his refusal to release his tax records to public scrutiny, as all nominees since the 1970s had done. His campaign's citing of an ongoing audit as an excuse for not releasing them raised one of two suspicions: that perhaps he is not even remotely as rich as he claims to be or that maybe, through financial maneuvering, he pays no taxes at all. The latter suspicion gained credence when a group of investigative journalists at the New York Times got ahold of a 1995 tax return in which the business mogul declared a \$916 million loss, which could have legally allowed him to avoid paying any income tax for up to two decades. ${ }^{\text {xxvii }}$ Since that point, concerns lingered about the discrepancy between his selfpromotion as a "winner" and how his track record of a series of bankruptcies suggested otherwise. 


\section{MALING FLIP FLOPS}

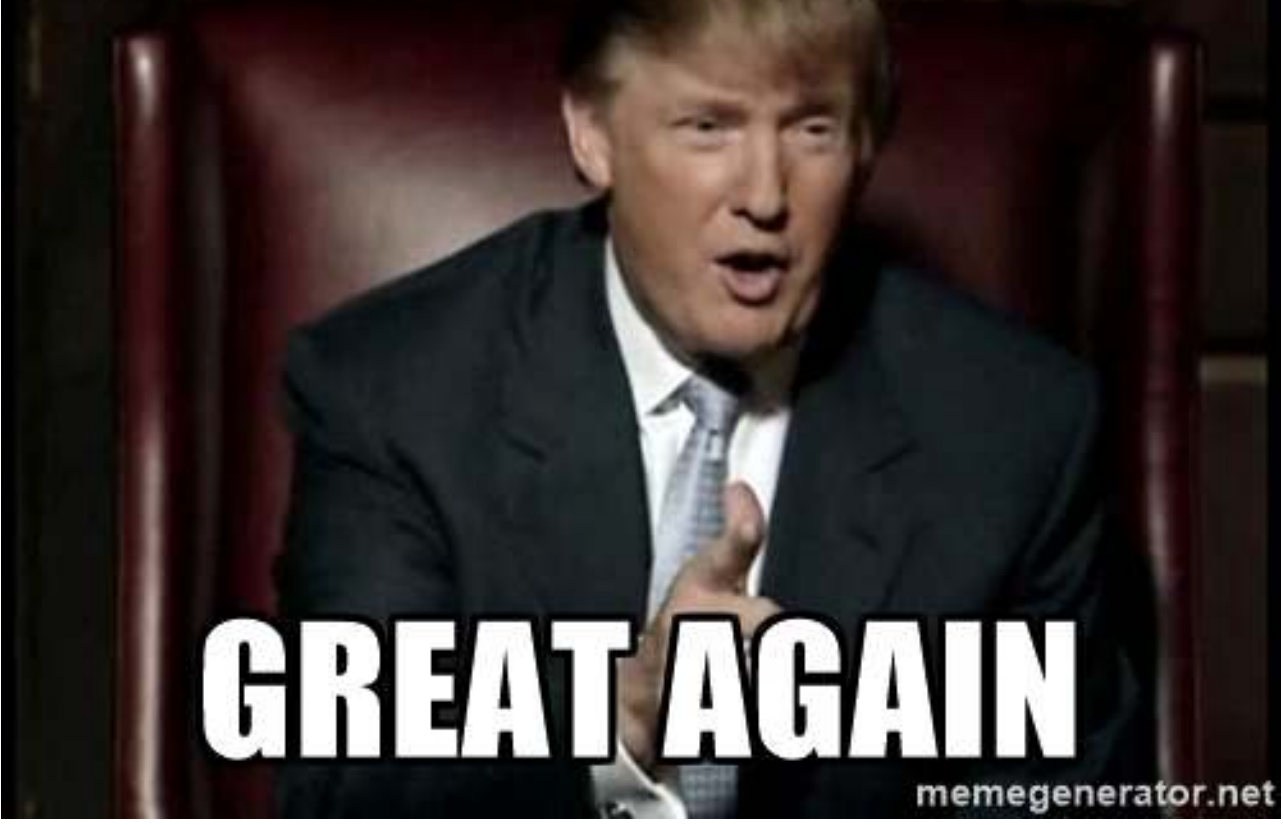

Figure 4. "Make Flip Flops Great Again," Meme Generator xxviii

The high unfavorability ratings that both parties' nominees grappled with made them look like liabilities in the eyes of many voters. Donald Trump's exceptional candidacy as an outsider, with no experience in foreign policy, served as a field day for mememakers. A popular Internet meme combined the lack of Trump's knowledge about policy substance with the perennial question of whether his hair is real, leading to the pun seen in Figure 5:

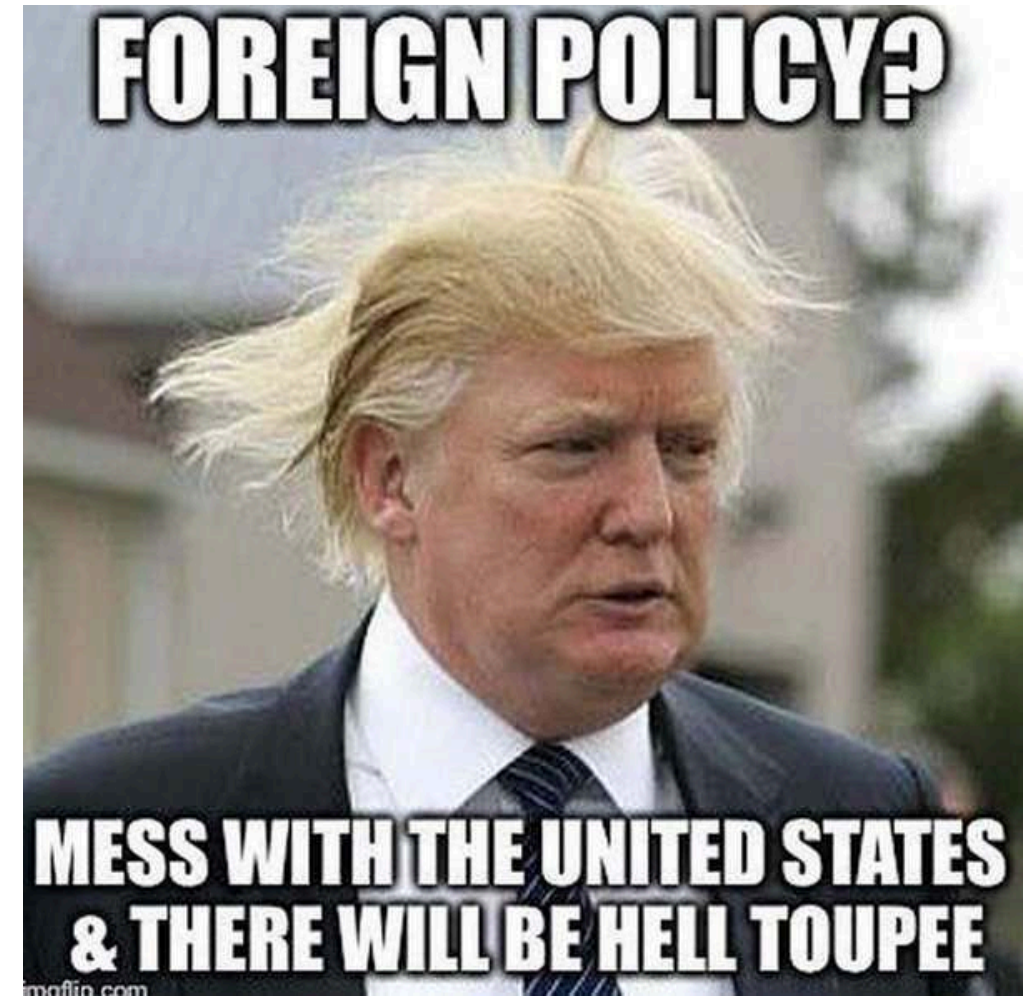



Clinton to be hawkish and trigger-happy, more akin to the neoconservatives of the
George W. Bush Administration than centrist Democrats. Meme-makers ran with the theme, as seen below.

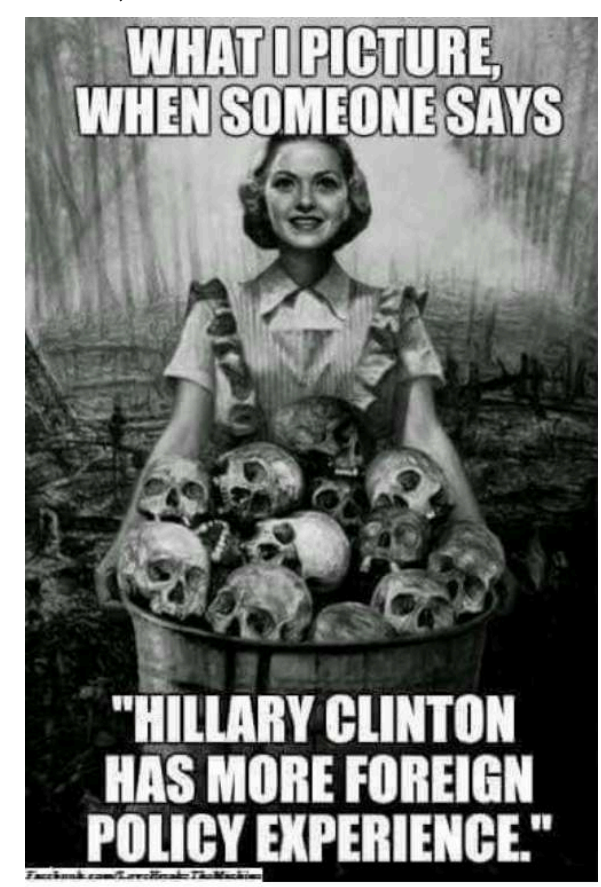

Hillary's Foreign Policy

Experience

Figure 6. "Hillary Clinton's Foreign Policy Experience," Sizzle. ${ }^{\text {xxxiii }}$

One of the most contentious foreign policy issues between the presidential nominees was their position on Russia and its leader, President Vladimir Putin. Throughout his campaign, Trump called for closer relations with Russia, despite the international community's sanctions on the Putin administration's actions in Ukraine and Crimea, both hotspots of geopolitical crisis in the region. Both men had expressed complimentary views about one another in public, raising much speculation about the nature of their prior dealings. The post-election revelations that Russia was behind the hacking of the Democratic National Committee's (DNC) network, possibly impacting the 
election result in favor of Trump, further aggravated the tensions. Having referred to both Trump and Putin as "bullies" in various public statements, Hillary Clinton had a more contentious relationship with Putin. During the 2008 election, Clinton had described Putin as a KGB agent, who "by definition... doesn't have a soul," to which Putin issued a stinging response: "I think at a minimum it's important for a government leader to have a brain." ${ }^{x x x i v}$

In addition to their controversial policy positions, the candidates were considered to have social liabilities. Trump's major liability was his unorthodox approach to political discourses. Although his outside-the-political-establishment language appealed to many in the Republican base, as well as disillusioned independents, the general consensus both outside and inside his campaign was that when given free range to speak-rather than reading a scripted message off of a teleprompter-any number of things could, and did, go wrong. Hillary Clinton's liability list was long as well, but perhaps the biggest baggage for her campaign was her husband. As the $42^{\text {nd }}$ President of the United States, William Jefferson Clinton was impeached by the House of Representatives in connection with his affair with a White House intern, Monica Lewinsky, and a sexual harassment lawsuit by the State of Arkansas employee Paula Jones. When Bill Clinton lied about the affair, his much-quoted line was: "I did not have sexual relations with that woman, Ms. Lewinsky." In the 2016 campaign, a spin-off meme was modified to reflect Hillary Clinton's Achilles's heel, the email scandal resulting from her use of a private email server during her tenure in the Obama administration, leading to allegations that her actions may have jeopardized national security (see Figures 7 and 8). As in many other elections with candidates who had high negativity ratings, ordinary people vowed to move to Canada, should either Trump or Clinton be elected.
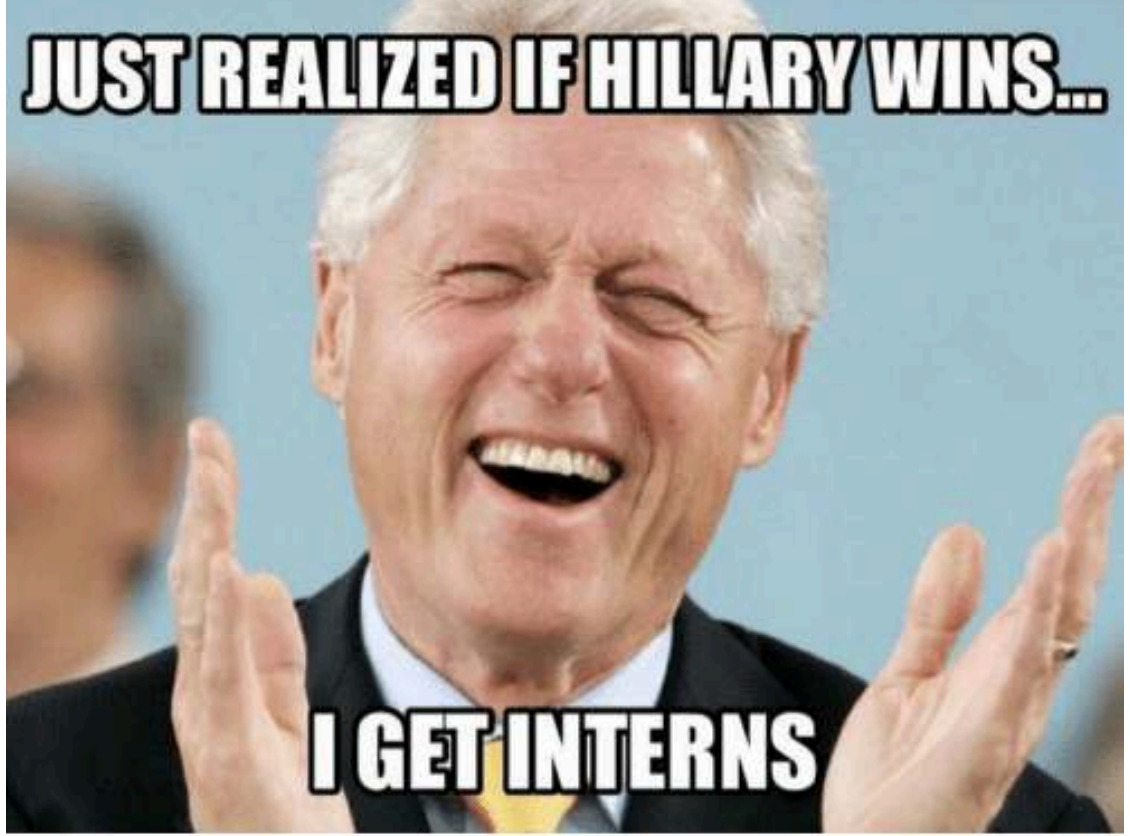

\section{Happy Bill...}

Figure 7. "Just Realized If Hillary Wins," Sizzle. ${ }^{\mathrm{xxv}}$ 


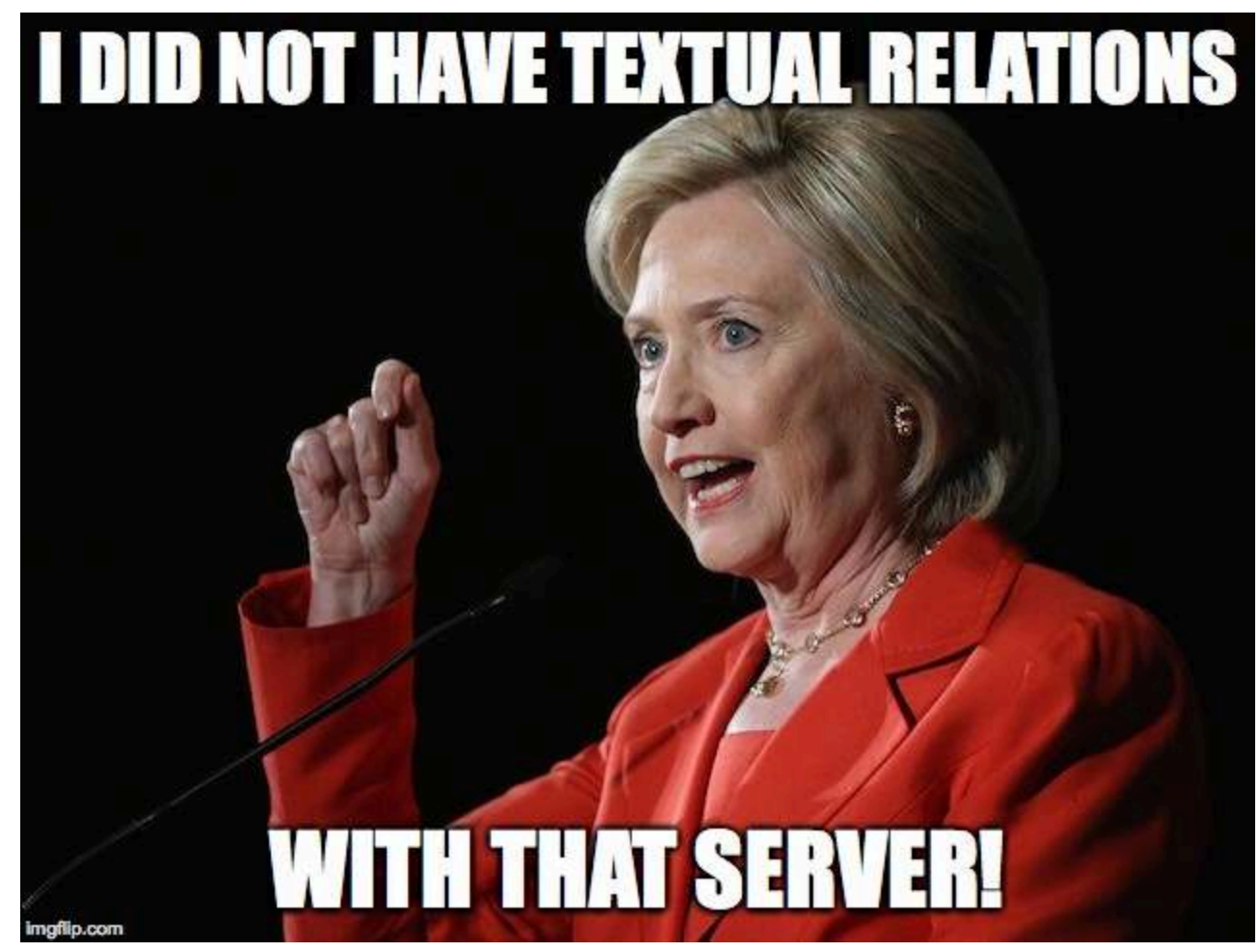

Figure 8. "Never Crooked Hillary," Pinterest. ${ }^{\text {xxxvi }}$

The beacon of Donald Trump's campaign was a slogan, "Make America Great Again," borrowed from Ronald Reagan's 1980 presidential bid. Throughout the 2016 race, questions were raised as to what previous era's "greatness" Trump might want to emulate: whether he was referring to the Founding Fathers (see Figure 9) or some other period. Although the campaign never issued any definitive answers to this, based on Trump's statements and policy proposals, some fascinating historical parallels can be drawn. Trump notoriously began his campaign with divisive rhetoric that demonized working-class Mexican immigrants and threatened to create a register to monitor Muslim immigrants. In a June 19, 2015 campaign speech in New York, given three days after announcing his candidacy, Trump proclaimed: "When Mexico sends its people, they're not sending their best.... They're sending people that have lots of problems, and they're bringing those problems with us. They're bringing drugs. They're bringing crime. They're rapists. And some, I assume, are good people."xxxvii The goal of building a 1000-mile wall on the approximately 2000-mile border between the United States and Mexico to keep out "criminals," "rapists," and "illegals" was the cornerstone of Trump's campaign. As many of the lowest-paying construction jobs are carried out by Latino workers-and often undocumented immigrants-the irony was that Donald Trump, a real estate tycoon and developer himself, regularly hired them for his own construction sites, thus undermining his own tough campaign rhetoric (Figure 10). 


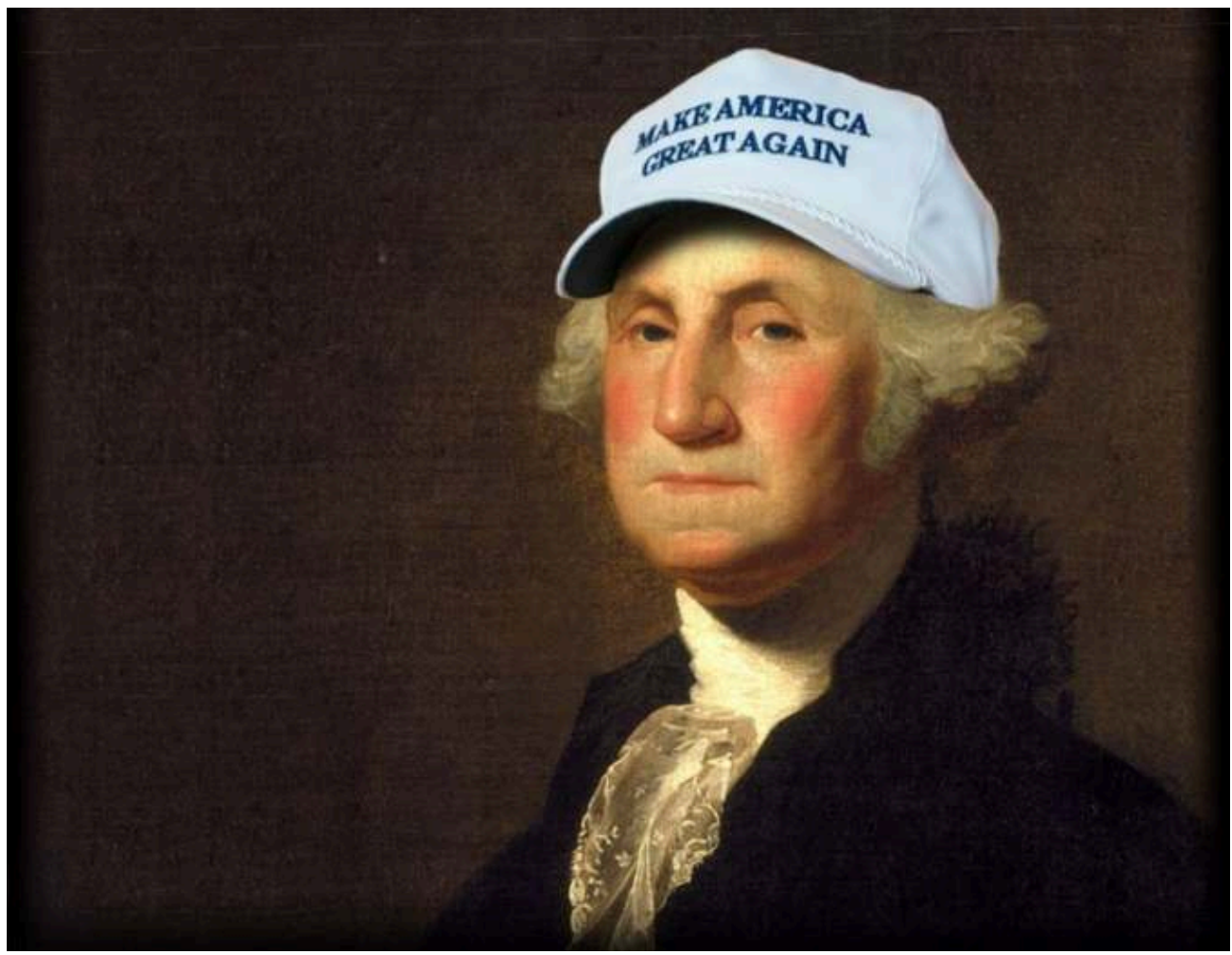

Figure 9. "Make America Great Again,” Know Your Meme. ${ }^{\text {xxxviii }}$

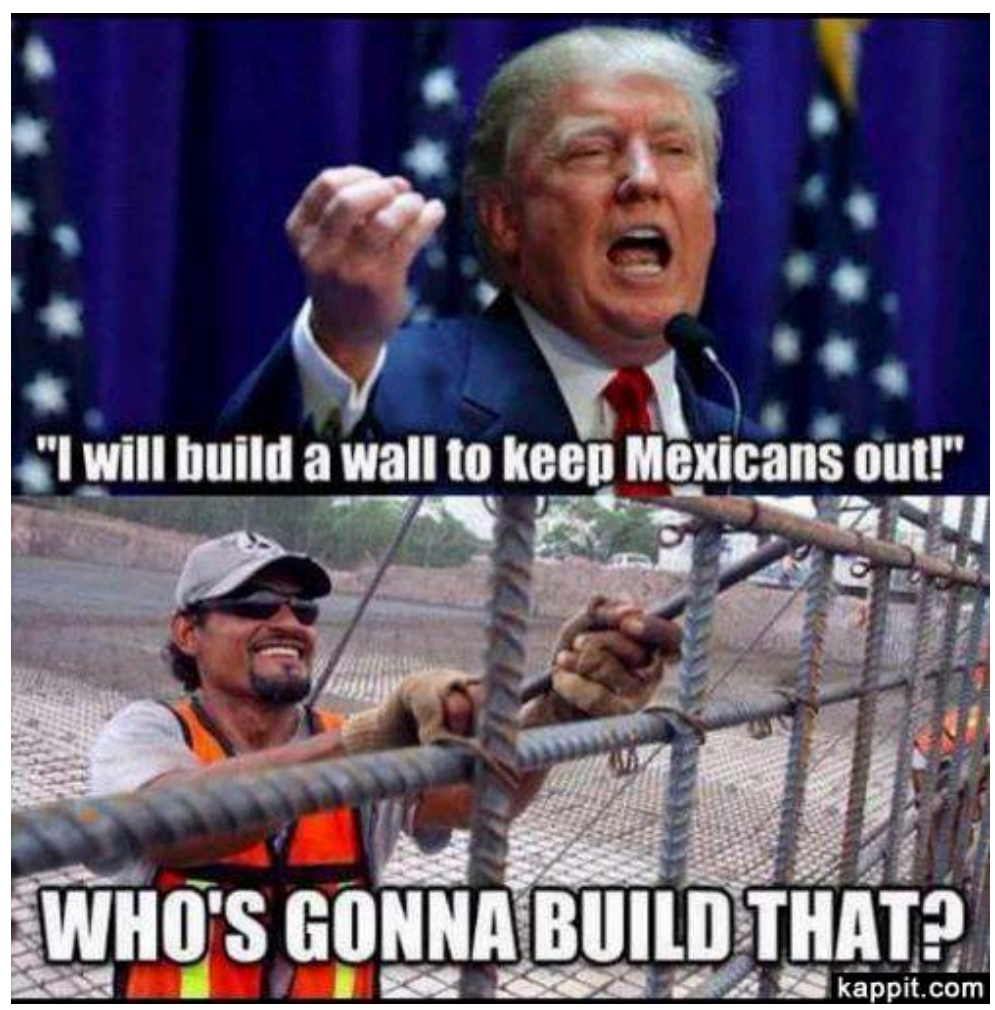

Figure 10. "I Will Build a Wall," Funny Captions. ${ }^{\text {xxxix }}$

Trump's xenophobic statements harken back to the nineteenth-century nativist movement, which attempted to restrict the right of certain ethnic and racial minorities, religious groups, and political radicals to gain U.S. citizenship and to hold public office. While the early nativists' targets-Germans, Irish, Southern Europeans, 
and Jews-have by the twenty-first century mostly "assimilated" into racialized "Whiteness," the tone of Trumpian neo-nativist rhetoric particularly targeted racialized minorities. The Trump campaign's links with various white supremacist groups also speak to nativist movements of old, such as the mid-nineteenth-century Know-Nothing Party, also known as the American Party. However, Trump not only vowed to keep immigrants out, but also to "drain the swamp" of establishment politics in Washington D.C.

\section{Social Power Relations Take Center Stage} -race and ethnicity, class, gender, and sexuality-were at the forefront of the 2016 election. The election became a locus of such struggles, bringing attention to existing socio-economic, cultural, and political tensions in the United States. On the Sunday before the election, the famed journalist Tom Brokaw described the divisive state of the nation in NBC's Meet the Press show as follows:

Well, you know, I've been at this for a fair amount of time. I have never seen the country so fractured as it is now. The Founding Fathers in their wisdom said, 'We, the people, in order to form a more perfect union.' This campaign has been, 'We, the African Americans, we, the Hispanics, we, the women, we, the angry white males, we, the wealthy, we, the people who don't know quite what to do.' We're in tribal warfare here. ${ }^{\mathrm{xl}}$

Above all, the election revealed a disconnect between the elites-both conservative and progressive-and so-called ordinary people from all walks of life. Whereas some commentators were envisioning a de facto "post-racial society" after Obama took office in 2008, the 2016 election indicated the opposite: that racial and ethnic tensions had intensified in society as a result of a class-based racist backlash. The past decades' demographic and economic shifts had resulted in a loss of social or economic poweroften both-for groups that felt marginalized in society. Class-based and racialized urban-rural divides were connected to questions of globalization, identity politics, and culture wars, as well as to whether people saw diversity as an opportunity or a threat. ${ }^{\mathrm{xli}}$ The adverse impact of globalization touched people in lower socio-economic positions in ways that its benefactors did not experience. Trump's rhetoric of fear and xenophobia during the campaign served as a channel for people's anxieties about their position in society. In one TV debate, for example, Trump referred to alleged Mexican "criminals as "bad hombres" (men) that should be deported from the United States. One of Hillary Clinton's major blunders during a campaign event was when she disparaged Trump's voters as a "basket of deplorables." The statement not only angered Trump's base, but also backfired by aggravating her elitist image as being out of touch with socalled ordinary people. 


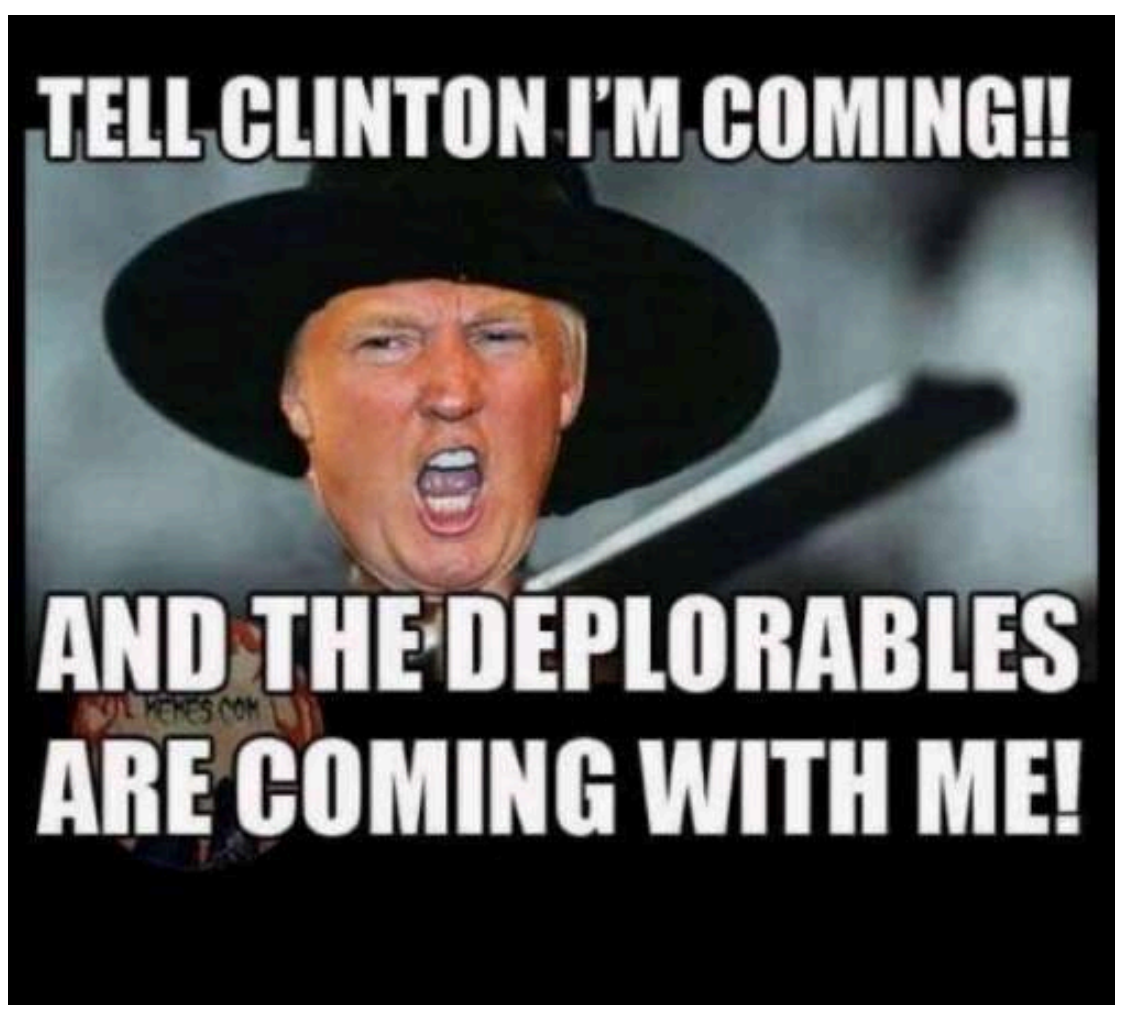

Figure 11. "I'm Coming," Pinterest.xlii

The gender divide during the election was obvious, with the first woman nominated for the U.S. presidency and over twenty men across the political spectrum challenging her politics. In television debates, different versions of manhood were on a collision course between the male and female candidates, Hillary Clinton and Carly Fiorina, the only Republican woman running for president. During the primaries, Donald Trump insulted Fiorina's appearance by provoking his supporters: "Look at that [Fiorina's] face! Would anyone vote for that?" In another debate, he referred to Hillary Clinton as a "nasty woman." Akin to how the Trump campaign successfully appropriated the term "Deplorables" (see Figure 11), Clinton's surrogates ran with the assault, making frequent references to the term, while sporting "Nasty Women" T-shirts. Both of the statements quickly attracted meme-makers. 


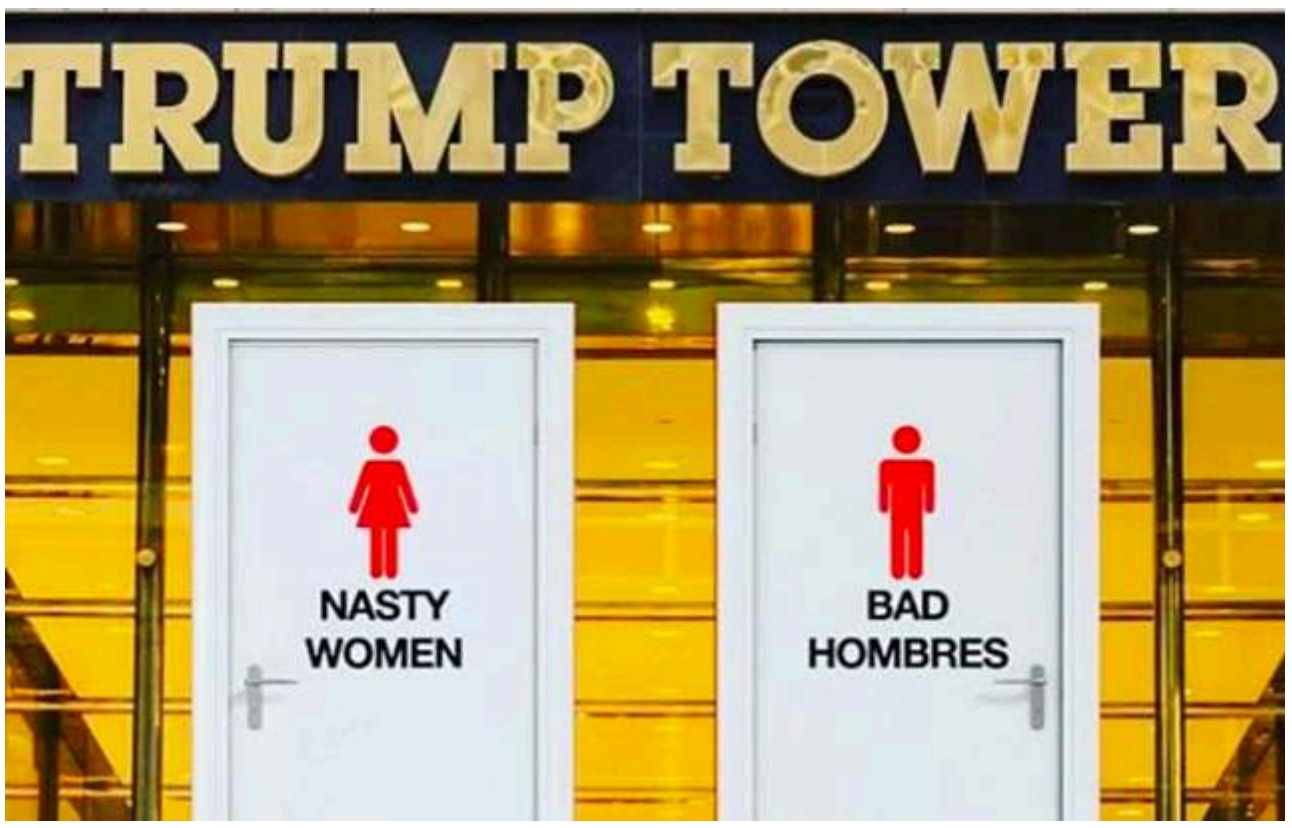

Figure 12. "Nasty Women, Bad Hombres," Queerty. ${ }^{\text {xliii }}$

Throughout her campaign, Hillary Clinton had a unique kind of gender problem. To the older generation of women, who identified with her, Clinton represented "pantsuit womanhood," the empowerment of professional women in the political arena, such as former Secretary of State Madeleine Albright or Chancellor Angela Merkel of Germany. On November 8, many of her supporters sported pantsuits to the election booth to specifically make a statement about her historic candidacy. However, two groups of women in particular did not buy into her representation of womanhood: conservative women and millennials. For many millennial women, shattering the glass ceiling in and of itself was not enough of a political movement; for them, progress was about a broader, intersectional egalitarian agenda, akin to the Occupy Wall Street Movement. Clinton's supporters never quite seemed to come to grips with why the twenty- and thirty-somethings would rather vote for a 74-year-old grumpy white man than join in electing the first woman president. The campaign was never able to resolve the issue. 
We call on all women to share the dood new that Bernie Sanders is the BEST candidate for women. He's not only excellent on traditional women's is rues. he is also a denuine Prodres dive on is sued ruch as the environment, education, rocial prodirams. civil riobhts, diplomacy, financial redulation. and more... \#FeelTheBern

Figure 13. "Women for Bernie Sanders," Imgur. xliv

Discourses of manhood during the election assumed meaning through metaphors of hand size, men's treatment of women, and sexual violence. During the primaries, Senator Marco Rubio (R-FL) retaliated against Trump's habit of referring to him as "Little Marco" by claiming that Trump had small hands, followed by the innuendo, "You know what they say about guys with small hands." xlv To the stupefaction of Fox's live audience, Donald Trump made it a point during the debate to refute Rubio's charge, also assuring people that there was "no problem" with the implied allegation (i.e., the size of his genitals). ${ }^{x l v i}$ In October, just four weeks before Election Day, a major scandal broke out. In a series of articles, the Washington Post reported on leaked tapes from 2005 in which the Republican nominee described his unsolicited sexual advances toward women, be they married or single: "I moved on her like a bitch... You know I'm automatically attracted to beautiful... I just start kissing them. It's like a magnet. Just kiss. I don't even wait... And when you're a star, they let you do it... Grab them by the p---y. You can do anything." ${ }^{\prime}$ lvii Although allegations about Trump's sexual harassment and rape charges had been widely reported in various media during the election, the leaked tapes provided evidence of his behavior directly from the horse's mouth. After the leaks, thousands of women broke their silence about experiences of sexual harassment, including more than a dozen who alleged victimization by Trump over the years. Notwithstanding the broad outrage about the leaks, commentators failed to understand that many of Trump's supporters did not consider such "locker-room talk" offensive; on the contrary, it may have even galvanized his voters. 

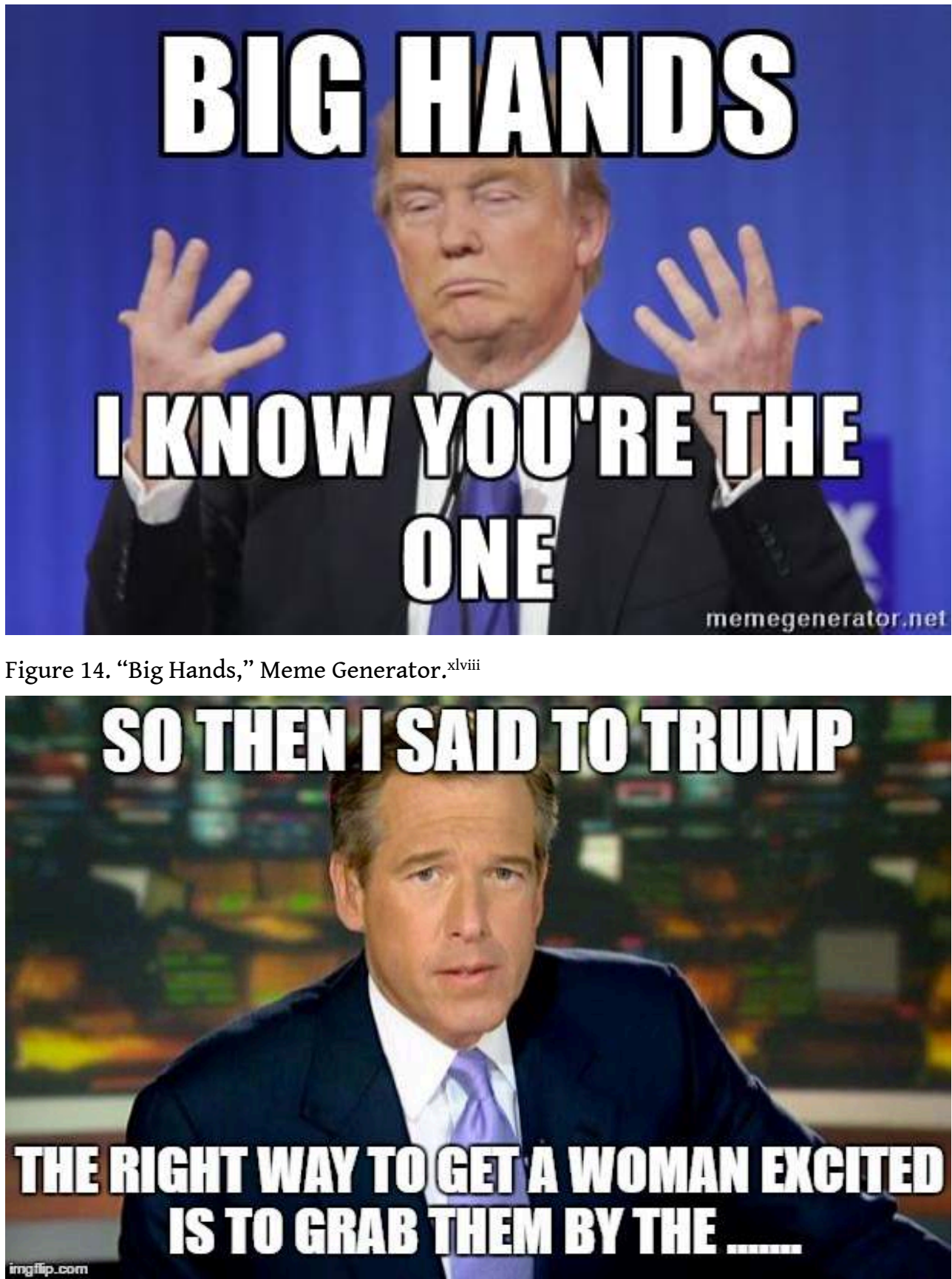

Figure 15. "So Then I Said," Imgflip. xlix

The final TV debate, which took place the week following the leaks, provided yet another curious turn of events in an already unusual presidential race. During the event, the question of sexual power relations took center stage at the debate. In response to the charges made against him, Trump brought as guests to the audience women who over the years had accused Bill Clinton of sexual harassment and rape. While many of these allegations had been settled outside of court, the Monica Lewinsky affair-also leaked to the public in taped phone conversations-was widely known all over the world. Whereas Clinton's campaign insiders and surrogates claimed that Hillary should not be responsible for her husband's deeds, and that the allegations stemmed back many decades, others were troubled by the notion of Bill Clinton returning to the White House as a first spouse. Both campaigns, then, were marred by a 
series of allegations of abuse of power in troubling ways. Whereas Hillary Clinton systematically denied the charges against her husband, Trump defended his own behavior by appealing to an accuser's appearance, as represented in the meme below: ${ }^{1}$

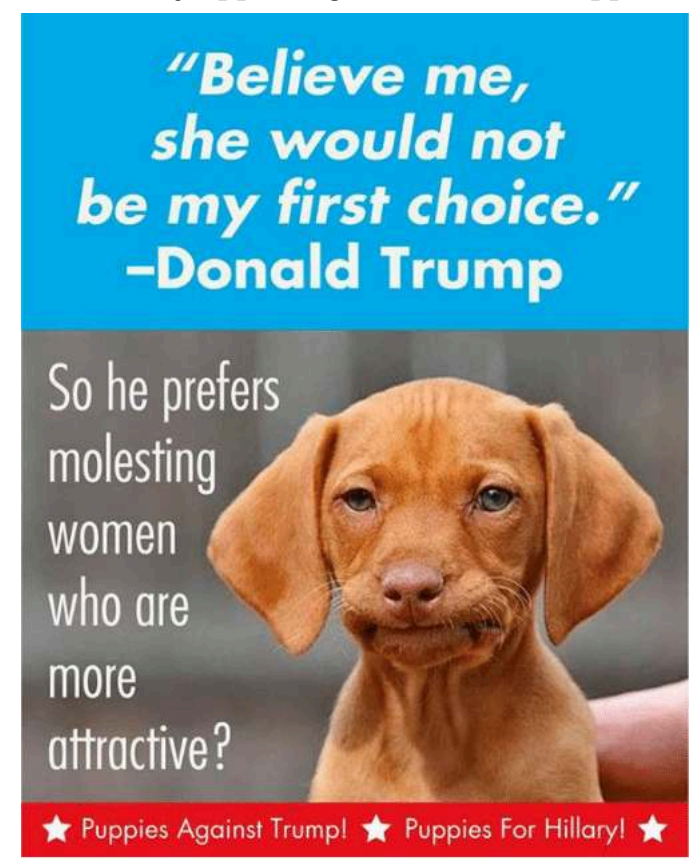

Trump belittles sexual assault accuser

Figure 16. "She Would Not Be My First Choice," Sizzle. ${ }^{\text {ii }}$

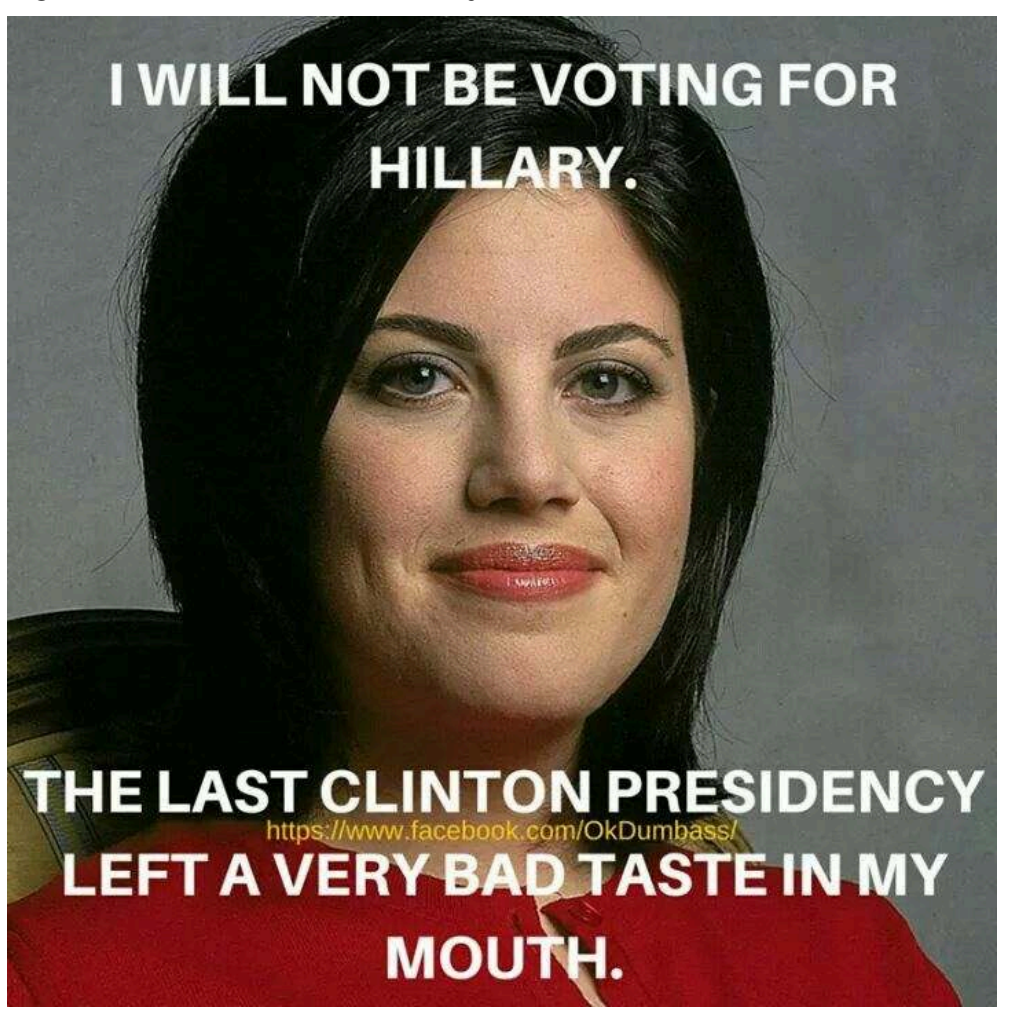

Figure 17, “I Will Not Be Voting for Hillary," Pinterest. ${ }^{\text {lii }}$ 

scandals and criminal allegations, small wonder that meme-makers represented the election as a choice between the lesser of two evils.

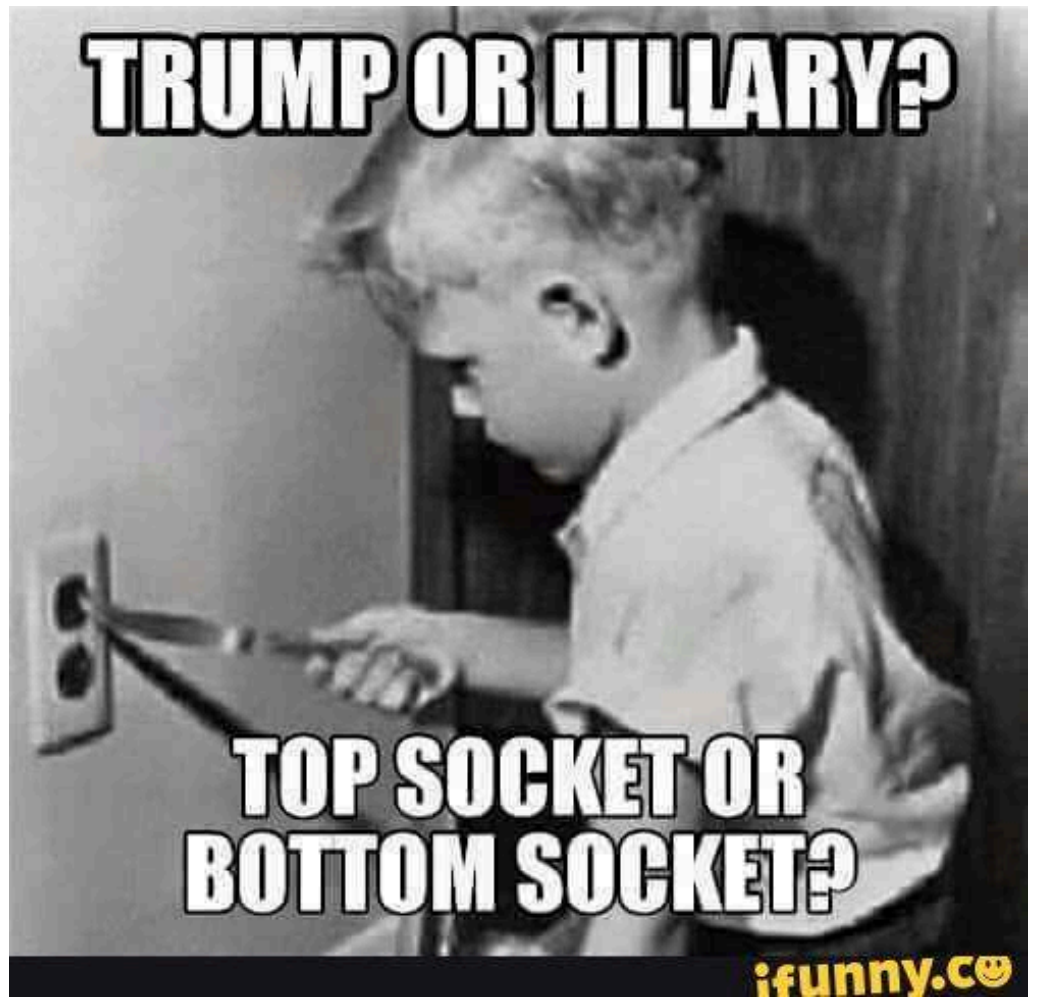

The focus on various social power relations that had been at the forefront of the 2016 election from the beginning of the primaries spoke to lingering divisions that the nation was-and is still-grappling with. While the Obama administration had pushed through various progressive reforms, including the Affordable Care Act, marriage equality, and energy programs, the Republican consensus has been to oppose, and ultimately overturn, these reforms at all costs. Majorities in the House and the Senate up until the 2018 midterms were thought to facilitate carrying out such an agenda. While the victory of Donald Trump stupefied political commentators the world over, President Obama assured the U.S. public in a statesmanlike manner that he would do everything in his power to make the transition of power as smooth as possible. Simultaneously, a series of widespread post-election memes began circulating, featuring imagined conversations between President Obama and Vice President Joe Biden. In these memes, Biden comes up with a range of mischievous pranks that the two discuss in a dialogue. The punchlines are directly related to the statements and positions heard during the 2016 campaign. To give a few examples of the dialogue: “Biden: I changed the wifi password. Obama: Joe...Biden: It's 'PssyGrbbr45' now. Obama: No, Joe. Biden..." The joke in this example is Trump's vulgar statements about women, discussed above, which created a global uproar. To quote another one, Obama asks: "Joe, why are you still holding my hand? Biden: I wanna freak Mike Pence out. Obama: But why? Biden: Just roll with it." "liv Voters familiar with Mike Pence's record as Governor of Indiana will know of his agenda to roll back the rights of same-sex couples, and therein lies the humor. In the third example, the joke is on the President-Elect: 
"Obama: Did you change all the toiletries with travel size bottles? Biden: He's got tiny hands, Barack. I wanted him to feel welcome."lv
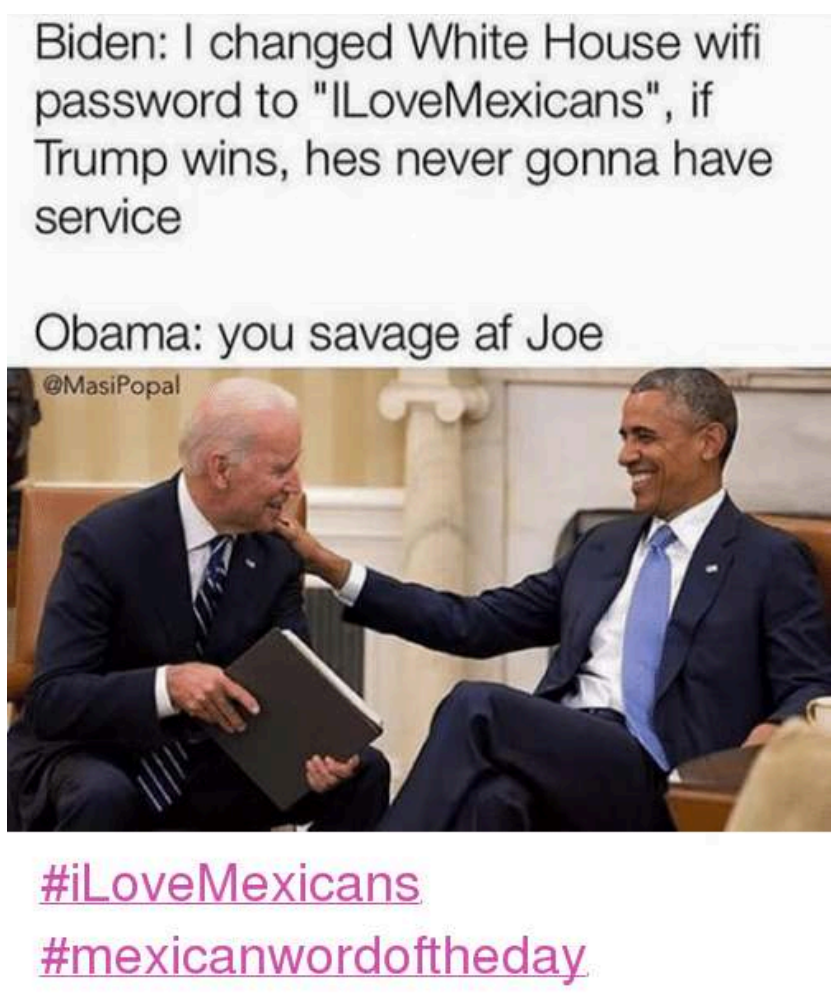

Figure 19. \#ILoveMexicans," Sizzle. lvi $^{\text {“4 }}$

The Obama/Biden (also known as "Jobama") memes could be interpreted as humorous responses to a situation that to many had seemed implausible and the consequences of which could only be imagined. Widely circulated in both mainstream media and social media, these memes served as venting tools for Obama/Biden supporters, who had managed to concoct, as CNN put it, a "massively nerdy presidential revenge fan fiction" right before their exit from the White House. lvii Obama and Biden, both of whom enjoyed high approval ratings on their departure, lvii had for years been open about their close relationship and "brotherhood," nicknamed in popular representations as a "bromance." The Obama/Biden memes seemed to ominously contrast their working relationship with that of the incoming President and Vice President, who seem to have preciously little in common, as they stepped into office. A month into his tenure, Vice President Pence was reported to have been kept in the dark about some top-level political maneuvering, including the details of phone calls made to Russia by Michael Flynn, Trump's National Security Adviser, who was forced to resign because of the scandal. ${ }^{\text {lix }}$ These revelations resulted in a flurry of questions as to who was really in charge of the everyday running of the White House and what the confidentiality level of the President and the Vice President were, as opposed to his two personal confidantes, former chair of Breitbart News Steven Bannon and son-in-law Jared Kushner. 


\section{Reflection: Epistemological Hierarchies}

46 My discussion of meme-ing, with examples from both the Republican and Democratic campaigns, illustrates the ways in which memes speak to the intersection of electoral activism and cultural representations: they enable users to rapidly take a stand on and react to developing political events in real time, they provide alternative parallel discourses to mainstream media viewpoints, and they enable mobilization of voters outside of official political discourses, including the potential to influence voting practices. Because memes are prompted by real-life events and perceptions, and spread both information and misinformation, critical questions have been raised as to whether voters can be trusted to differentiate between the two. An article written by Benjamin Powers, published by Paste in April 2016, expresses the following concerns:
Memes are a problem because they grossly oversimplify well, essentially everything. If the substance of our politics was decided totally by labeling candidates and their supporters as 'stupid' or utilizing 'pixie dust' to pay for education, then memes would be great. But that's not the actual substance or implications of our politics. The creation and formulation of policy is complicated and nuanced, neither of which are words the least bit associated with memes.... Memes are constantly shared on Twitter and fall into [a] category of a medium for information that can at worst be categorically wrong and at best reductive of much more complicated issues. As we continue to bemoan the state of American politics and democracy, it's worth thinking about the fact that if we love memes so much, what does that say about us and our preferred engagement with the democratic process? ${ }^{\mathrm{lx}}$

Stefka Hristova, in turn, takes issue with the viewpoint that memes might serve as a site for dissent; on the contrary, in his view, they have the potential to "neutralize" dissent by establishing "normative narratives":

They emerge at moments of contestation of dominant narratives and through their participatory structure of imitation and mutation, they allow for the dissolution of points of ideological conflict as well as for the reestablishment of a normative narrative. If not too threatening to the health of the state body, these cultural viruses are left unchecked as they build immunity... of the nation-state. ${ }^{\text {lxi }}$

On the one hand, memes violate conventional practice in that they bring political discourses to sites that are not considered as established platforms for bipartisan politics. On the other hand, they are produced by a group of people who are not typically involved in electoral politics. Distributed in real time on platforms that are within the users' own comfort zones, they effectively spatialize political participation outside of mainstream partisan forums and media outlets. When they spread on social media, memes quickly reach a global audience, with endless possibilities for reinterpretation and circulation.

These critiques, which attempt to delegitimize meme-ing, call attention to specific epistemological debates that Internet memes have evoked about hierarches of knowledge, the right and access to certain types of information online, and the practice of political representation. According to a study conducted by Peter Lundgren, the socalled "dot.net generation" is generally unlikely to either get involved in traditional politics or promote political engagement. ${ }^{\text {lxi }}$ Most of the users of the Bernie Sanders Dank Meme Stash, however, were not only millennials, but among the younger echelon, between the ages of 18 to 21 . . $^{\text {liii }}$ According to a poll conducted by right-wing political consultant Frank Lunz in February 2016, U.S. voters between the ages of 18 to 26 were 
"extremely liberal," with 66\% choosing a Democratic candidate; of these, $31 \%$ identified with Sanders, $18 \%$ with Obama, and $11 \%$ with Clinton. ${ }^{\text {lxiv }}$ The entire process of the youth-led meme-ing phenomenon thus took place outside the control of political and media gatekeepers, enabling challenges of status quo representations. In an article entitled "The Court of Memes: Why People Believe Fake Facts," Steven J. Allen warns that "false memes often have very real effects, providing the basis for bad laws that hurt people, or twisting people's views of history to make them easier prey for extremist politicians." ${ }^{\mid x v}$ Such criticism represents what Michel Foucault has described as a tension between "erudite knowledge and a popular knowledge." stems from a division between established, scientific discourses and disqualified or subjugated "insurrection of knowledges," which are opposed to "the effects of the centralising powers." ${ }^{x v i i}$ Foucault writes:

I believe that by subjugated knowledges one should understand something else, something which in a sense is altogether different, namely, a whole set of knowledges that have been disqualified as inadequate to their task or insufficiently elaborated: naive knowledges, located low down on the hierarchy, beneath the required level of cognition or scientificity. ${ }^{\text {.xviii }}$

50 Foucault continues by arguing, as cited in the epigraph of this article, that it is precisely such "low-ranking," popular knowledges that allow criticism to work, albeit in opposition to the "general politics of truth" of various societies. ${ }^{\text {lxix }}$ Following Foucault, I want to conclude in this article that meme-ing in the 2016 presidential election contributed to a wider phenomenon of decentering knowledge production processes.

51 As a form of popular or "naïve" knowledge, Internet memes provide parallel discourses to the many other public discussions related to the election, pointing to some of the tensions evident in official and unofficial representations. As examples of what Foucault refers to as "those disqualified from the hierarchy of knowledges and sciences," Internet memes show the ways in which representational politics are tied to questions of individual and collective agency. ${ }^{1 \times x}$ The fact that they are distributed in social media demonstrates how space is used for the politics of representation. The controversy surrounding memetic representations exemplifies a split between formal and informal ways of producing knowledge about issues with global relevance. Such an effect may have been heightened in connection with discussions about the post-factual era, which have become central to understanding Donald Trump's candidacy.

52 I would, however, draw a distinction between Internet memes and post-factual messaging. Unlike so-called fake news, Internet memes are a recognizable genre that should not be conflated with news or any other factual representation. Even as they serve as sites for personal interventions, and are embedded with persuasive functions, it is easy to differentiate them from news reporting. The background images borrowed from popular culture texts, the distinct layout, and the superimposed text by default suggest humorous constructions. Because social media is appropriated for the distribution of memes, they become one site of what Doreen Massey describes as a "knowledge/power relation which was mirrored in a geography that was also a geography of power." "|xxi Rather than factually reproducing news items, Internet memes penetrate official discourses by carnivalizing them. In lieu of silencing such representations, it is important to take them seriously as sources that go beyond official, public discourses. Indeed, we would do well to consider a range of informal 
communication networks as sources of information on a nuanced understanding of electoral politics and beyond.

\section{NOTES}

i. Dawn Chmielewski, “Internet Memes Emerge as 2016 Election's Political Dog Whistle," USA Today, October 2, 2016, accessed December 30, 2016, http://www.usatoday.com/story/tech/news/2016/09/30/internet-memes-white-house-electionpresident/91272490/.

ii. Michel Foucault, Power/Knowledge: Selected Interviews and Other Writing, 1972-1977, ed. Colin Gordon, trans. Leo Marshall, John Mepham, Kate Soper (New York: Pantheon, 1980), 82.

iii. Caitlin Dewey, "How Bernie Sanders Became the Lord of 'Dank' Memes," Washington Post, February 23, 2016, accessed January 2, 2017,

https://www.washingtonpost.com/news/the-intersect/wp/2016/02/23/how-bernie-sandersbecame-the-lord-of-dank-memes/?utm_term=.5c50826b7fob.

iv. Leigh Alexander, "Blame it on the Zodiac Killer: Did Social Media Ruin Ted Cruz's Campaign?" Guardian, May 4, 2016, accessed August 21, 2016,

https://www.theguardian.com/media/2016/may/04/ted-cruz-campaign-social-media-memeszodiac-killer.

v. Anastasia Denisova, "Memes, Not Her Health, Could Cost Hillary Clinton the US Presidential Race," Independent, September 12, 2016, accessed January 1, 2017,

http://www.independent.co.uk/voices/hillary-clinton-health-pneumonia-political-memesa7238581.html.

vi. Alex Williams, "How Pepe the Frog and Nasty Woman Are Shaping the Election," New York Times, October 28, 2016, accessed January 2, 2017,

https://www.nytimes.com/2016/10/30/style/know-your-meme-pepe-the-frog-nasty-womanpresidential-election.html.

See also Abby Ohlheiser, “'We Actually Elected a Meme as President': How 4chan Celebrated Trump's Victory," Washington Post, November 9, 2017, accessed January 2, 2017, https://www.washingtonpost.com/news/the-intersect/wp/2016/11/09/we-actually-elected-ameme-as-president-how-4chan-celebrated-trumps-victory/?utm_term=.23b2db9de135.

vii. Rodney Taveira and Emma Balfour, "How Donald Trump Won the 2016 Meme Wars," Conversation, November 30, 2016, accessed December 30, 2016,

http://theconversation.com/how-donald-trump-won-the-2016-meme-wars-68580.

viii. "Election 2016: Campaigns as a Direct Source of News," Pew Research Center, July 2016, accessed November 30, 2016, http://www.journalism.org/2016/07/18/election-2016-campaignsas-a-direct-source-of-news/.

ix. Electmeme.lol, accessed January 2, 2017, http://www.electmeme.lol/.

x. Jenna Lever, "Bernie Sanders Has the Dankest Memes on the Internet," ReverbPress, January 24, 2016, accessed August 21, 2016, http://reverbpress.com/politics/bernie-sanders-has-thedankest-memes-on-the-internet/.

xi. Memecenter. accessed January 2, 2017, http://www.memecenter.com/fun/6056279/feel-dabern. 
xii. For specific examples, please see the discussion in the section entitled "Reflection: Hierarchies of Knowledge" in this article.

xiii. Richard Dawkins, The Selfish Gene (Oxford: Oxford University Press, 1976), 206.

xiv. Heidi E. Huntington, "Pepper Spray Cop and the American Dream: Using Synecdoche and Metaphor to Unlock Internet Memes' Visual Political Rhetoric," Communication Studies 67, no. 1 (2016): 77-93.

xv. Limor Shifman, Memes in Digital Culture (Cambridge, MA: MIT Press, 2013).

xvi. Stefka Hristova, "Visual Memes as Neutralizers of Political Dissent," tripleC 12, no. 1 (2014):

265-276, accessed January 3, 2017,

http://www.triple-c.at/index.php/triplec/article/view/507.

xvii. Shifman, 15.

xviii. Ryan Milner, "Pop Polyvocality: Internet Memes, Public Participation, and the Occupy Wall Street Movement. International Journal of Communication 7 (2013): 2357-2390. [2357 \& 2360].

xix. On the intersection of popular culture and politics, see John Street, Sanna Inthorn, and Martin Scott, From Entertainment to Citizenship: Politics and Popular Culture (Manchester: Manchester University Press, 2013), Liesbet Van Zoonen, Entertaining the Citizen: When Politics and Popular Culture Converge (Lanham, MD: Rowman and Littlefield, 2005), and Lane Crothers and Charles Lockhart, eds., Culture and Politics: A Reader (New York: St. Martin's Press, 2000).

xx. Political cartoons, especially in newspapers, may enable readers to comment on them, but they are not able to recreate them, restricted as they are by copyright. On the participatory nature of memes and digital culture, see Shifman; José van Dijk, "Users Like You? Theorizing Agency in User-generated Context," Media, Culture \& Society 31, no. 1 (2009): 41-48; and Henry Jenkins, Convergence Culture: Where Old and New Media Collide (Cambridge, MA: MIT Press, 2006).

xxi. Vasiliki Plevriti, "Satirical User-Generated Memes as an Effective Source of Political Criticism, Extending Debate and Enhancing Civic Engagement," M.A. Thesis, University of Warwick, 2014.

xxii. Reddit, accessed February 20, 2017,

https://www.reddit.com/r/PoliticalHumor/comments/3292ci/

2016_election_worst_regifting_ever/.

xxiii. Google, accessed February 20, 2017,

https://www.google.fi/search?

$q=$ sequel+of $+a+$ sequel\&espv=2\&biw=914\&bih=440\&source=lnms\&tbm=isch\&sa=X\&ved=0ahUKEwiF8YL9y57SAhWJfywKHVqjBZgQ_AUIBi xxiv. Imgur, accessed January 6, 2017, http://imgur.com/gallery/vZ4bjDb.

xxv. See Aaron Smith, “The Internet's Role in Campaign 2008," Pew Research Center, April 15, 2009, accessed January 6, 2017, http://www.pewinternet.org/2009/04/15/the-internets-role-incampaign-2008/; Soumitra Dutta and Matthew Fraser, "Barack Obama and the Facebook Election," US News, November 19, 2008, accessed January 6, 2017, http://www.usnews.com/ opinion/articles/2008/11/19/barack-obama-and-the-facebook-election; Journalism \& Media Staff, "How the Presidential Candidates Use the Web and Social Media," Pew Research Center, August 15, 2012, accessed January 6, 2017, http://www.journalism.org/2012/08/15/howpresidential-candidates-use-web-and-social-media/; and Jenna Wortham, "The Presidential Campaign in Social Media," New York Times, October 8, 2016, accessed January 6, 2017, http://www.nytimes.com/interactive/2012/10/08/technology/campaign-social-media.html? _r $=0$.

xxvi. Imgur, accessed January 6, 2017, http://i.imgur.com/lZ1PCjD.jpg.

xxvii. David Barstow, Susanne Craig, Russ Buettner, and Megan Twohey, "Donald Trump Tax Records Show He Could Have Avoided Taxes for Nearly Two Decades, The Times Found," New York Times, October 1, 2016, accessed January 6, 2017, http://www.nytimes.com/2016/10/02/us/politics/donald-trump-taxes.html. xxviii. Accessed January 6, 2017, 
https://cdn.meme.am/cache/instances/folder890/500x/66327890.jpg.

xxix. Accessed January 6, 2017, https://i.imgflip.com/mzui4.jpg.

xxx. Cited in Melissa Chan, "Here's What Donald Trump Has Said About Nuclear Weapons," Time, August 3, 2013, accessed January 6, 2017, http://time.com/4437089/donald-trump-nuclearweapons-nukes/.

xxxi. Ibid.

xxxii. Eun Kyung Kim, “Can Donald Trump win? 'Anything is possible,' Obama Tells Savannah Guthrie,” Today, July 27, 2016, accessed January 6, 2017,

http://www.today.com/news/can-donald-trump-win-anything-possible-obama-tells-savannahguthrie-t101191.

xxxiii. Sizzle, accessed January 6, 2017, https://onsizzle.com/i/nwhatipictur-whensomeonesays-hillary-clinton-has-more-foreign-policy-experience-872352.

xxxiv. Damian Paletta, "Clinton vs. Trump: Where They Stand on Foreign Policy Issues," Wall Street Journal, undated, accessed January 6, 2017,

http://graphics.wsj.com/elections/2016/donald-trump-hillary-clinton-on-foreign-policy/.

xxxv. Sizzle, accessed January 6, 2017, https://pics.onsizzle.com/just-realized-if-hillary-winsget-interns-happy-bill-3220264.png.

xxxvi. Pinterest, accessed January 6, 2017,

https://www.pinterest.com/pin/684899055800766714/.

xxxvii. Tal Kopan, "What Donald Trump has Said about Mexico and vice versa," CNN Politics, August 31, 2016, accessed February 20, 2017,

http://edition.cnn.com/2016/08/31/politics/donald-trump-mexico-statements/.

xxxviii. Accessed January 6, 2017,

http://i3.kym-cdn.com/photos/images/original/001/041/260/0ab.png.

xxxix. Funny Captions, accessed January 6, 2017,

http://www.funnycaptions.com/img/198533/i-will-build-a-wall-to-keep-mexicans-out-whosgonna-build-that/.

xl. Meet the Press, NBC News, November 6, 2016, accessed January 7, 2017, http://www.nbcnews.com/meet-the-press/meet-press-november-6-2016-n678646.

xli. For discussions of class and twenty-first-century U.S. politics, see Thomas Frank, What's the Matter with Kansas?: How Conservatives Won the Heart of America (New York: Picador, 2004) and J.D. Vance, Hillbilly Elegy: A Memoir of a Family and Culture in Crisis (London: William Collins, 2016).

xlii. Pinterest, accessed January 6, 2017,

https://www.pinterest.com/pin/387028161711225631/.

xliii. Queerty, accessed January 6, 2017,

https://queerty-prodweb.s3.amazonaws.com/content/docs/2016/10/20124330/Screen-

Shot-2016-10-20-at-11.27.14-AM.png.

xliv. Imgur, accessed January 6, 2017, http://i.imgur.com/H8FcwCM.png.

xlv. Alexandra Jaffe, "Donald Trump Has 'Small Hands, Marco Rubio Says," NBC News, February 29, 2016, accessed January 6, 2017, http://www.nbcnews.com/politics/2016-election/donaldtrump-has-small-hands-marco-rubio-says-n527791.

xlvi. Gregory Krieg, "Donald Trump Defends the Size of His Penis," CNN Politics, March 4, 2016, accessed January 6, 2017, http://edition.cnn.com/2016/03/03/politics/donald-trump-smallhands-marco-rubio/.

xlvii. David A. Fahrenthold, "Trump Recorded Having Extremely Lewd Conversation about Women in 2005," Washington Post, October 8, 2016, accessed January 6, 2017,

https://www.washingtonpost.com/politics/trump-recorded-having-extremely-lewdconversation-about-women-in-2005/2016/10/07/3b9ce776-8cb4-11e6-

bf8a-3d26847eeed4_story.html?utm_term =.a8f08da81f31.

xlviii. Meme Generator, accessed January 6, 2017, 
https://memegenerator.net/instance/67265342.

xlix. Imgflip, accessed January 6, 2017, https://imgflip.com/i/1c5l91.

1. Jose A. DelReal, "Trump Mocks Sexual Assault Accuser: "She Would Not be My First Choice," Washington Post, October 14, 2016, accessed January 7, 2017,

https://www.washingtonpost.com/news/post-politics/wp/2016/10/14/trump-mocks-sexualassault-accuser-she-would-not-be-my-first-choice/?utm_term=.

li. Sizzle, accessed January 6, 2017, https://pics.onsizzle.com/believe-me-she-would-not-be-myfirst-choice-donald-4929199.png.

lii. Pinterest, accessed January 6, 2017, https://fi.pinterest.com/pin/326229566741641669/.

liii. Accessed January 6, 2017, http://images.memes.com/meme/905031.

liv. Tim Dowling, "How Joe Biden Became the US's Meme-in-Chief," The Guardian, November 14, 2016, accessed January 7, 2016,

https://www.theguardian.com/global/shortcuts/2016/nov/14/how-joe-biden-became-the-usmeme-in-chief.

lv. Sage Lazzaro, "21 Hilarious Memes of Joe Biden and Obama's Imagined Conversations about Pranking Trump," Observer, November 14, 2016, accessed January 9, 2017,

http://observer.com/2016/11/21-hilarious-memes-of-joe-biden-and-obamas-imagined-

conversations-about-pranking-trump.

lvi. Sizzle, accessed January 6, 2017, https://pics.onsizzle.com/Facebook-iLoveMexicansmexicanwordoftheday-c89c7d.png.

lvii. A.J. Willingham, "The 11 Best Joe Biden Memes as America Says Bye to its Uncle-in-Chief," CNN Politics, January 12, 2017, accessed Fenbruary 20, 2017,

http://edition.cnn.com/2016/11/14/politics/joe-biden-memes-trnd/.

lviii. Gallup, accessed February 20, 2017, http://www.gallup.com/poll/202349/president-obamaleaves-white-house-favorable-rating.aspx.

lix. Julie Pace and Viviana Savana, "Trump kept Pence in the dark for weeks over Flynn-Russia call, officials say," Chicago Tribune, February 15, 2017, accessed February 20, 2017,

http://www.chicagotribune.com/news/nationworld/politics/ct-trump-pence-michael-flynnrussia-20170215-story.html.

lx. Benjamin Powers, "How Memes Perfectly Capture What's Wrong With Our Political Engagement," Paste, April 5 2016, accessed August 13, 2016,

https://www.pastemagazine.com/articles/2016/04/how-memes-perfectly-capture-whats-wrongwith-our-p.html.

lxi. Stefka Hristova, "Visual Memes as Neutralizers of Political Dissent," tripleC 12, no. 1 (2014): 265-276, accessed January 2, 2017,

http://www.triple-c.at/index.php/triplec/article/view/507.

1xii. Peter Dahlgren, Media and Political Engagement: Citizens, Communication and Democracy (Cambridge: Cambridge University Press, 2009).

lxiii. Leigh Alexander, "Blame it on the Zodiac Killer." The Guardian, May 4, 2016, accessed February 20, 2017, https://www.theguardian.com/media/2016/may/04/ted-cruz-campaignsocial-media-memes-zodiac-killer.

lxiv. Jon Schwarz, "The GOP Pollster: Young Americans Are Terrifyingly Liberal," The Intercept, February 24 2016, accessed January 2, 2017,

https://theintercept.com/2016/02/24/top-gop-pollster-young-americans-are-terrifyingly-

liberal/.

lxv. Steven J. Allen, "The Court of Memes: Why People Believe Fake Facts," Capital Research, August 12, 2016, accessed January 7, 2016, https://capitalresearch.org/article/the-court-ofmemes-why-people-believe-fake-facts.

lxvi. Michel Foucault, Power/Knowledge, 81-84.

lxvii. Ibid., 84. 
lxviii. Ibid., 82.

lxix. Ibid., 82 and 131.

lxx. Ibid., 82.

lxxi. Doreen Massey, For Space (London: SAGE, 2005), 64.

\section{ABSTRACTS}

In February 2016, the Washington Post characterized the presidential primaries as "the mostmemed election in U.S. history." During the election year, meme-ing related to the major candidates became hugely popular and engaged various groups of people who were not ordinarily involved in bipartisan political processes. As brief, to the point, and quickly modifiable visual-textual messages, Internet memes were a particularly apt way to illustrate the most contested hot-button issues that emerged during the 2016 presidential race. This article considers the phenomenon of meme-ing in relation to both the Republican and Democratic campaigns. In particular, it focuses on memes that called attention to the candidates' contradictory or incongruous statements critiquing their policy positions. The article demonstrates the ways in which memes spoke to the intersection of electoral activism and cultural representations in several ways: they enabled users to rapidly take a stand on and react to developing political events in real time; they provided alternative parallel discourses to mainstream media viewpoints; and they enabled mobilizing voters outside of official political discourses. During the 2016 campaign, meme-ing served as an example of a politico-cultural discourse that exemplified the unusual election year in ways that conventional political analysis alone was not able to capture.

\section{INDEX}

Keywords: Internet memes, 2016 U.S. presidential election, electoral participation, mememaking, politico-cultural discourses, knowledge production 